\title{
FENOMENA PERKAWINAN TIDAK TERCATAT DI KOTA BIMA
}

\author{
Zuhrah $^{1}$, Husnatul Mahmudah ${ }^{2}$, Juhriati $^{3}$ \\ STIH Muhammadiyah Bima ${ }^{1}$, IAI Muhammadiyah Bima ${ }^{2}$, STIH Muhammadiyah Bima ${ }^{3}$ \\ zhoemacy@gmail.com¹, arraynez@gmail.com, juhriati@stihm-bima.ac.id ${ }^{3}$
}

\begin{abstract}
Abstrak. Perkawinan adalah pelembagaan hubungan laki-laki dan perempuan dalam membentuk sebuah keluarga. Tetapi pelembagaan tersebut tentunya semua masyarakat menginginkan pelembagaan yang sah dan tercatat pada lembaga perkawinan Negara. Hal tersebut dimaksudkan untuk melindungi hak-hak perempuan dan anak. Akan tetapi keinginan tersebut tidak serta merta berjalan sesuai kehendak, sehingga muncullah fenomena perkawinan tidak tercatat. Pada tulisan ini diangkat tentang Fenomena Perkawinan Tidak Tercatat di Kota Bima dengan spesikasi lokus di kecamatan Raba, Kecamatan Asakota dan Kecamatan Rasanae Barat yang masing-masing mengambil sampel tiga kelurahan per kecamatan. Perkawinan tidak tercatat merupakan sebuah pelembagaan perkawinan yang tidak sah dan tidak tercatat pada lembaga perkawinan Negara. Hal tersebut disebabkan oleh beberapa factor, diantaranya adalah pendidikan pasutri yang rendah sehingga tidak berpikir akibat hokum perkawinan yang dilakukan dengan tidak tercatat. Yang kedua adalah poligami dimana suami menikah tanpa izin istri terdahulu, ketiga adalah Married by Accident (MBA) yakni adanya insiden hamil di luar nikah sehingga dianggap sebagai aib lalu dikawinkan oleh masyarakat. Keempat adalah perkawinan kedua dan seterusnya setelah menduda atau menjanda. Ketika pasangan suami isri sudah tidak memikirkan tentang keabsahan secara administrasi Negara atau konsekuensi hokum lain seperti waris mewarisi atau lainnya, sehingga mereka berpikir bahwa perkawinan tersebut merupakan bentuk kebersamaan yang tidak mempertentangkan tentang harta perkawinan atau harta warisan.
\end{abstract}

\section{Kata Kunci: Fenomena Perkawinan Tidak Tercatat}

\section{PENDAHULUAN}

\section{Latar Belakang}

Setiap manusia memiliki hak asasi untuk melanjutkan keturunannya melalui perkawinan, yakni melaksanakan suatu perkawinan yang dilaksanakan menurut kebudayaan dan kepercayaan (agama) masing-masing. Perkawinan merupakan ikatan lahir batin antara seorang pria dengan seorang wanita sebagai suami istri dengan tujuan membentuk keluarga atau rumah tangga yang bahagia dan kekal berdasarkan Ketuhanan Yang Maha Esa, sebagaimana diatur dalam Pasal 1 Undang-Undang No. 1 Tahun 1974 tentang Perkawinan (selanjutnya disebut UU Perkawinan). Setiap orang atau pasangan yang sudah melakukan perkawinan maka terhadapnya ada ikatan kewajiban dan hak diantara mereka berdua dan anak-anak yang lahir dari perkawinan tersebut.

Sebelum lahirnya UU Perkawinan, ketentuan, tatacara dan sahnya suatu perkawinan bagi orang Indonesia pada umumnya didasarkan pada hukum agama dan hukum adat masing-masing. Menurut hukum adat, perkawinan adalah suatu ikatan antara seorang laki-laki dengan seorang perempuan untuk membentuk rumah tangga yang dilaksanakan secara adat dan agamanya dengan melibatkan keluarga kedua belah pihak saudara maupun kerabat.

Aturan ini kemudian dirasa sudah tidak relevan lagi dengan kebutuhan dan permasalahan-permasalahan yang timbul saat ini. Syarat perkawinan yang hanya dilakukan berdasarkan agama dan hukum adat, tidak menjamin adanya kepastian hukum bilamana dikemudian hari terjadi suatu peristiwa hukum atau konflik diantara kedua belah pihak.

Setelah berlakunya UU Perkawinan, maka terjadi unifikasi hukum dalam perkawinan di Indonesia, dimana perkawinan mempunyai hubungan yang sangat erat dengan agama. Pengaturan hukum tentang perkawinan telah berlaku sama terhadap semua warga Negara. Oleh karena itu, setiap warga Negara harus patuh terhadap hukum 
yang berlaku, termasuk terhadap UU Perkawinan yang menjadi landasan untuk menciptakan kepastian hukum, baik dari sudut hukum keluarga, harta benda, dan akibat hukum dari suatu perkawinan.

Pasal 2 ayat (1) UU Perkawinan menjelaskan bahwa "Perkawinan adalah sah apabila dilakukan menurut hukum masingmasing agama dan kepercayaan itu." Ketentuan itu menggambarkan prinsip Pancasila yang pertama yaitu "Ketuhanan Yang Maha Esa". Hal itu merupakan prinsip utama dari sahnya perkawinan dan suatu bentuk tolerasansi antar umat beragama. Berlanjut pada Pasal 2 ayat (2) UU Perkawinan menerangkan bahwa "Tiap-tiap perkawinan dicatat menurut peraturan perundang-undangan yang berlaku." Artinya di Indonesia, yang mennetukan sahnya sebuah perkawinan adalah apabila dilakukan menurut hokum agama dan kepercayaan, bukan pada sisi pencatatannya.

Terkait hal tersebut, dapat dipahami bahwa pencatatan perkawinan bukan menjadi penentu sah tidaknya suatu perkawinan. Hal ini yang kemudian menjadi faktor yang mengakibatkan banyak orang tidak melakukan pencatatan pada Kantor Catatan Sipil atau Kantor Urusan Agama (KUA) bagi orang Muslim. Pada sisi lain, ketentuan ini merupakan suatu kesatuan yang tidak dapat dipilih keberlakuannya. Pada saat hanya memenuhi salah satu ketentuan saja, maka peristiwa perkawinan tersebut belum memenuhi unsur hukum yang ditentukan oleh Undang-Undang. Hal tersebut berarti, apabila ada suatu sengketa antara suami istri yang perkawinannya tidak dicatatkan, maka salah satu pihak yang bersengketa tidak dapat melakukan penuntutan.

Persoalannya adalah pada saat ini banyak sekali anak-anak yang tidak mendapat pengakuan dari ayah biologisnya karena perkawinan antara ibu-bapaknya dilakukan tanpa melalui prosedur pencatatan atau lazim dalam masyarakat disebut sebagai pernikahan siri. Akibatnya, anak tidak memiliki akta lahir, padahal akta lahir sangat penting sebagai bukti otentik yang menjamin kepastian hukum. Selain itu, apabila ada kekerasan dalam rumah tangga atau hak istri tidak dipenuhi oleh suami, istri tidak dapat mengajukan tuntutan karena status perkawinannya tidak sah dimata hukum, sehingga negara tidak dapat memberikan perlindungan hukum untuk menjamin hakhaknya.

Pencatatan perkawinan bukan persoalan sepele, karena hal ini berkaitan dengan keberlangsungan rumah tangga khusunya berkaitan dengan kepentingan sang anak. Belum adanya pemahaman secara mendalam mengenai pencatatan perkawinan membuat masyarakat terutama di daerah pelosok daerah kerap melakukan pernikahan sirri yang biasanya berujung perceraian.

\section{TINJAUAN PUSTAKA}

Perkawinan yang tidak dicatatkan menjadi problema kekinian tetapi pelaku nikah tidak tercatat tidak jera melakukannya. Hal ini dikarenakan tidak tegasnya sanksi yang diberikan dan sekalipun ada regulasi masih bisa ditinjau kembali melalui judicial review di Mahkamah Konstitusi. Adapun tulisan tentang Perkawinan yang tidak tercatat pernah ditulis oleh Khoirul Abror dalam makalahnya yang berjudul Problematika Nikah Tidak Tercatat Antara Hukum Nasional dan Hukum Islam. Dalam makalah tersebut, Khoirul Abror menjelaskan bahwa Nikah sirri dilakukan karena hubungan yang tidak direstui oleh orang tua dari kedua belah pihak atau salah satu pihak, nikah sirri dilakukan karena alasan tidak memiliki anak bertahuntahun, nikah siri dilakukan karena terjadinya perselingkuhan, nikah sirri dilakukan karena menghindari dosa karena zina.

Muhammad Lukman Hakim menulis tentang Kebijakan Itsbat Nikah Terhadap Pernikahan Tidak Tercatat Dalam Buku Register Nikah (Studi Analisis di KUA Kecamatan Singorojo Kabupaten Kendal). Penelitian ini menghasilkan beberapa poin, yakni pertama kebijakan itsbat nikah terhadap pernikahan yang tidak tercatat dalam buku register tersebut kebijakan diambil dari Pengadilan Agama itu, di dalam ketentuan pasal 7 Kompilasi Hukum Islam (KHI) karena pertimbangan maslahah bagi umat Islam untuk mengurus dan mendapatkan hakhaknya 
yang berupa surat-surat atau dokumen pribadi.

Menelusuri makna dibalik fenomena perkawinan di bawah umur dan perkawinan tidak tercatat yang dieditori oleh Kustini adalah kumpulan tulisan yang mendeskripsikan tentang fenomena perkawinan di bawah umur dan perkawinan tidak tercatat pada beberapa daerah diantaranya Tangerang Banten, Indramayu Jawa Barat, Brebes Jawa Timur, Cianjur Jawa Barat, Kota Yogyakarta, Bangkalan Madura, Malang Jawa Timur, Nusa Tenggara Barat, Balangan dan Amuntai Kalimantan Timur. Semua tulisan yang tersebar di wilayah tersebut memaparkan data tentang fenomena perkawinan di bawah umur dan perkawinan yang tidak dicatatkan.

Anisahuri menulis tentang

Kemudharatan Nikah yang tidak Tercatat (Analisa Fatwa MUI Nomor 10 Tahun 2008 tentang Nikah di Bawah Tangan) pada tahun 2017. Tulisan ini mendeskripsikan bahwa menurut Majelis Ulama Indonesia, nikah yang tidak dicatat diharamkan karena terdapat beberapa unsur negatif (mudharat) di dalamnya. Namun demikian, MUI memandang pernikahan tersebut tetap sah. Adapun dalil yang digunakan oleh MUI terdiri dari dalil Alquran dan hadis yang berkaitan dengan keharusan bagi masyarakat untuk mentaati pemerintah (ulil amri). Salah satunya yaitu memenuhi ketentuan Pasal 2 ayat (2) Undang-Undang No. 1 Tahun 1974 tentang Perkawinan, dan Pasal 5 ayat (1) Kompilasi Hukum Islam tentang pencatatan nikah. Adapun metode yang digunakan MUI adalah metode sadduz-zari'ah dan metode mashlahah mursalah.

Andi Mutmainnah A. Mirri pada tahun 2018 menulis tentang Perkawinan tidak Tercatat di Kecamatan Tanasitolo Kabupaten Wajo (Tinjauan UU No. 1 Tahun 1974 dan Kompilasi Hukum Islam). Hasil penelitian ini menunjukkan bahwa perilaku atau peristiwa terjadinya perkawinan tidak tercatat di kantor urusan agama, itu terjadi karena dipicu oleh beberapa faktor yaitu faktor usia, faktor biaya dari para pelaku nikah, sulitnya aturan berpoligami, kawin lari, faktor agama, hamil diluar nikah, kurangnya pemahaman dan kesadaran masyarakat tentang pencatatan. Adapun akibat hukum yang ditimbulkan dari perkawinan yang tidak tercatat yaitu perkawinan dianggap tidak sah, anak hanya mempunyai hubungan perdata dengan ibu dan keluarga ibu, istri maupun anak tidak dapat menuntut nafkah dan warisan dari ayahnya. Selain itu, dampak sosial yang ditimbulkan dari peristiwa tersebut yaitu sang istri dan anak yang dilahirkan dari perkawinan tidak tercatat akan sulit bersosialisasi dengan masyarakat lainnya. Guna mengatasi berbagai faktor penghambat dan mencegah munculnya akibat hukum dan dampak sosial dari peristiwa perkawinan tidak tercatat maka KUA bersama dengan pemerintah setempat lebih berperan aktif dalam mengatasi terjadinya perkawinan yang tidak tercatat.

Kebijakan Itsbat Nikah Terhadap Pernikahan Yang Tidak Tercatat Dalam Buku Register Nikah (Studi Analisis di KUA Kecamatan Singorojo Kabupaten Kendal) Penelitian ini berhasil ditelusuri dengan beberapa poin yaitu pertama kebijakan itsbat nikah terhadap pernikahan yang tidak tercatat dalam buku register tersebut kebijakan diambil dari Pengadilan Agama itu, di dalam ketentuan pasal 7 Kompilasi Hukum Islam (KHI) karena pertimbangan maslahah bagi umat Islam untuk mengurus dan mendapatkan hak-haknya yang berupa surat-surat atau dokumen pribadi yang dibutuhkan dari instasi yang berwenang serta memberikan jaminan perlindungan kepastian hukum terhadap masing-masing pasangan suami istri, termasuk perlindungan terhadap status anak yang lahir dari perkawinan itu, dan perlindungan terhadap akibat hukum yang akan muncul kemudian. Kedua penyebab pernikahan yang tidak tercatat dalam buku register nikah disebabkan kelalaian Pengawai Pencatat Nikah (PPN), karena pada waktu itu Kantor Urusan Agama (KUA) tempatnya belum menetap sedangkan pernikahannya tersebut juga dilaporkan di Kelurahan sehingga tercatat dalam buku register Desa di kelurahan Merbuh dan secara resmi. 
Jenis penelitian ini adalah penelitian lapangan (field research) dimana peneliti berada langsung di lapangan yang dalam hal ini melakukan wawancara terhadap Subjek ataupun stake holder yang khusus menangani kasus Perkawinan tidak tercatat dengan menggunakan purposive sampling yakni pengambilan sampel untuk tujuan tertentu.

Data yang dibutuhkan dalam penelitian ini ada dua, yaitu data primer dan data sekunder. Data primer merupakan data utama yang diperoleh dari hasil wawancara mendalam (in depth interview), diantaranya:

1) Pemerintah Kelurahan, Kepala Dusun, Ketua-ketua RT

2) Subyek pelaku perkawinan tidak tercatat. Pada penelitian ini diambil lokasi di Kota Bima dengan mengambil 2 (dua) kecamatan yang terdiri dari 6 (Enam) kelurahan.

Data-data dalam penulisan ini diperoleh dengan empat metode.

a. Metode observasi yakni dengan pengamatan terhadap gejala yang diteliti. Dalam hal ini panca indera manusia (penglihatan dan pendengaran) diperlukan untuk menangkap gejala yang diamati. Apa yang ditangkap tadi dicatat yang selanjutnya untuk dianalisis. Pengamatan dalam hal ini adalah pengamatan terhadap realita Perkawinan tidak tercatat pada masyarakat Kota Bima maupun data-data yang ada di Kelurahan atau Kepala Dusun.

b. Metode in-depth interview (wawancara mendalam) yaitu metode pengumpulan data dengan jalan komunikasi, yakni melalui kontak atau hubungan pribadi antara pengumpul data (pewawancara) dengan sumber data (responden).

c. Metode dokumentasi, yaitu mendapatkan data sekunder untuk mendukung data primer penelitian. Adapun dokumentasi yang dilakukan adalah data Perkawinan tidak tercatat pada pemerintah Kelurahan setempat.

d. Studi pustaka pada referensi yang relevan.

Prosedur penelitian ini dimaksudkan untuk mendapatkan data primer maupun data sekunder selengkap mungkin, sebagai bahan penjelasan terhadap permasalahan yang diteliti. Dalam tulisan ini, penulis menggunakan analisis deduktif yakni dengan memaparkan secara umum lalu diambil kesimpulan yang bersifat khusus. Penggunaan analisis deskriptif yaitu untuk memberi gambaran atau menjelaskan fenomena perkawinan tidak tercatat di Kota Bima, sedangkan untuk analisis eksplanatorinya untuk menguji suatu teori atau hipotesis guna memperkuat atau bahkan menolak teori dari hasil penelitian yang sudah ada

\section{Data Perkawinan Tidak Tercatat}

\section{A. Kecamatan Raba}

Kecamatan kota Bima terdiri dari sebelas kelurahan/desa diantaranya Kendo, nitu, Ntobo, penanae, penaraga, Rabadompu barat, Rabadompu timur, Rabadompu Selatan, Rabadompu Utara, Rite, dan Rontu. Untuk penelitian ini hanya menggunakan tiga sampel di tiga kelurahan/desa yang ada di kecematan Raba yaitu kelurahan penanae, Ntobo, dan nitu

\section{Kelurahan penane}

Wilayah kelurahan Penanae dengan luas $5,34 \mathrm{~km} 2$, Kelurahan penanae yang berbatasan dengan keluharan Ntobo sebelah timurnya, kelurahan Rite sebelah barat, kelurahan Penatoi sebelah utara, dan Rabadompu Timur sebelah selatan. Jumlah penduduk kelurahan penanae sebanyak 4.335 jiwa dengan kepadatan penduduk sebanyak 812 jiwa, dengan jumlah laki-laki sebanyak 2.145 jiwa dan perempuan sebanyak 2.190 jiwa. Dengan rata-rata anggota rumah tangga 4 orang.

Di kelurahan tersebut berdasarkan hasil wawancara dengan pegawai kantor kelurahan terdapat 14 keluarga yang pernikahannya tidak tercatat oleh negara. Ini membuktikan bahwa masih saja ada warga negara yang pernikahannya tidak melibatkan pegawai pencatat nikah.

\section{Kelurahan Ntobo}

Kelurahan Ntobo dengan luas 31,19 $\mathrm{km} 2$, Jumlah penduduk sebanyak 3.113 jiwa, jumlah penduduk laki-laki sebanyak 1.561 jiwa dan perempuan 1.552 jiwa, dengan kepadatan penduduk 100. Dan ratarata anggota rumah tangga 4 orang.

Di kelurahan Ntobo Untuk data nikah tidak tercatat sesuai dengan hasil wawancara kami deangan pegawai kantor kelurahan 
setempat bahwa mereka menyatakan sejauh ini tidak ditemukan kasus nikah tidak tercatat dan kami juga turun langsung di salah satu Ketua RT setempat dan menyatakan tidak ada dari warganya yang nikah tidak tercatatkan.

\section{Kelurahan Nitu}

Kelurahan Nitu dengan luas 6,19 km2, Jumlah penduduk sebanyak 1.208 jiwa, jumlah penduduk laki-laki sebanyak 634 jiwa dan perempuan 574 jiwa, dengan kepadatan penduduk 195. Dan rata-rata anggota rumah tangga 4 orang.

Kelurahan Nitu yang berada pada geografisnya di atas gunung sebelah selatan kota Bima, sehingga mayoritas penduduk bekerja sebagai petani dan juga terdapat ibuibu yang bekerja sebagai penenun sarung adat Bima. Dengan kondisi tersebut ketika musim hujan banyak masyarakat yang menanam jagung disekitar jalan hingga jauh mata memandangnya dengan indahnya gunung yang dimiliki desa nitu,

Kelurahan Nitu tediri dari 8 RT, berdasarkan penelitian terdapat pernikahan tidak tercatat sebanyak 3 kasus, yang terdapat di RT 5, dan dua kasus terdapat di RT 2.

\section{B. Kecamatan Asakota}

Meskipun keharusan melakukan pencatatan perkawinan telah diatur dalam undang-undang, namun masalah pencatatan perkawinan sebagai tanda sahnya sebuah perkawinan masih terus disosialisasikan dengan tujuan untuk memberikan kemudahan kepada masyarakat dalam hal mengurus administrasi kependudukan dan berbagai keperluan lain. Adapun sebaran data pernikahan yang tercatat dapat dilihat dalam table berikut:

\begin{tabular}{|l|l|l|l|l|l|}
\hline \multirow{2}{*}{ No } & Lokasi & \multicolumn{4}{|c|}{ Tahun } \\
\cline { 2 - 6 } & & 2016 & 2017 & 2018 & 2019 \\
\hline 1 & $\begin{array}{l}\text { Di } \\
\text { KUA }\end{array}$ & 176 & 161 & 82 & - \\
\hline 2 & $\begin{array}{l}\text { Di } \\
\text { Luar } \\
\text { KUA }\end{array}$ & 13 & 15 & 12 & - \\
\hline & Jumlah & 189 & 176 & 104 & \\
\hline
\end{tabular}

C. Kecamatan Rasanae Barat
Adapun hasil penelitian di tiga kelurahan kec. Rasana'e Barat terkait dengan data nikah tidak tercatat

\section{Kelurahan sarae}

Merupakan Salah satu dari kelurahan yang berada di kec. Rasana,e Barat dengan jumlah penduduk: 6.014 jiwa dengan rincian jumlah kk: 1. 382 yang laki: 2.996 dan perempuan: 3.018. Adapun jumlah nikah yang tidak tercatat di kel. Sarae dengan hasil wawancara dengan pegawai di kel. Sarae yakni di $\mathrm{rt}$ 03 rw 01. Sebanyak 3 kasus sedangkan rt.04 rw.02 sebanyak 03 kasus juga namun untuk rt.03 rw.01 tersisa tinggal 1 dikarenakan akhir tahun kemarin mereka mengajukan isbat nikah untuk mendapatkan legalitas ataupun buku nikah. Jadi hasil untuk nikah tidak tercatat di kel. Sarae yakni sebanyak 4.

\section{Kelurahan Paruga}

Dengan jumlah penduduk: 7043 jiwa dengan rincian jumlah kk sebanyak: 1765 dengan jumlah laki: 3250 perempuan: 3793. Adapun nikah yang tidak tercatat sesuai dengan hasil wawancara di kantor kel. Paruga dengan perwakilan $2 \mathrm{rt}$ yakni ketua rt.17 dan rt. 18.

Dari pengakuan masing2 ke 2 narasumber tersebut ada sebanyak ada 2 kasus dan juga ada pengakuan juga dari rt lain yang saya datangi ada 2 kasus juga terkait dengan nikah tidak tercatat tsb.

\section{Kelurahan Pane}

Adapun data terkait masalah nikah tidak tercatat di kel. Pane yakni dengan jumlah penduduk: 3.100 dengan jumlah kk:1.153 dan jumlah laki:1.463 dan perempuan: 1 . 637. Untuk data nikah tidak tercatat di kel. Pane sesuai dengan hasil wawancara kami bahwa mereka menyatakan sejauh ini tidak di temukan kasus nikah tidak tercatat dan kami juga turun langsung di salah satu ketua rt setempat dan menyatakan tidak ada dari warganya yang nikah tidak tercatatkan.

\section{Faktor Terjadinya Perkawinan Tidak} Tercatat 
Dilihat dari data perkawinan tidak tercatat pada tiga kecamatan di Kota Bima yang dijadikan sampling penelitian tidak terlalu signifikan. Dan setelah dilakukan wawancara maka diketahui faktor terjadinya perkawinan tidak tercatat sebagai berikut:

1. Berpendidikan Rendah

Prosesi perkawinan tidak mensyaratkan harus berpendidikan tinggi, karena perkawinan merupakan urusan sacral dan fundamental bagi setiap warga Negara. Akan tetapi, secara interaksi social, tingkat pendidikan berpengaruh pada pola piker hidup dan kehidupan. Dalam hal ini, subjek yang melakukan perkawinan tanpa mengetahui wawasan tentang hak dan kewajiban maupun konsekuensi menikah berdampak pada kehidupan akan dating. Sebagai contoh kasus, yakni perkawinan yang tidak dilaporkan ke pegawai pencatat nikah oleh warga Negara yang memiliki latar belakang pendidikan rendah sehingga tidak mengetahui konsekuensi hokum secara administrasi akibat perkawinan yang tidak dicatatkan di kantor urusan perkawinan.

Secara administrasi, tidak legalnya perkawinan melalui akta Nikah akan mengakibatkan sang anak tidak diakui oleh Negara apabila berurusan dengan pendidikan, nafkah, waris atau lainnya. Begitu juga dengan perempuan sebagai istri, apabila dikemudian hari terjadi halhal diluar dugaan, maka dia tidak bisa mengajukan keberatan pada hal waris atau nafkah.

2. Keinginan Poligami (Tanpa Izin Istri Terdahulu)

Secara Islam, sunnah Nabi yang berisitri lebih dari satu seringkali menjadi tameng bagi laki-laki untuk berpoligami dengan alasan belum memiliki keturunan, istri yang memiliki penyakit menahun atau alasan lainnya. Sehingga fenomena dalam masyarakat saat ini adalah poligami tanpa izin istri terdahulu untuk beristri lagi. Poligami tersebut dilakukan tanpa dicatatkan pada pegawai pencatat nikah, karena syarat menikah lebih dari satu istri atau poligami pada lembaga perkawinan negara harus mendapat izin dari istri terdahulu.

Fenomena poligami liar ini menjadi salah satu factor adanya kasus perkawinan yang tidak dicatatkan. Tetapi secara hokum tetap memiliki konsekuensi yang tidak baik bagi sang anak ataupun istri. Karena tidak memiliki legalitas administrasi secara hokum nasional, maka kedudukan anak dan istri di depan hokum tidak sah dan dianggap sebagai anak diluar perkawinan.

3. Married By Accident (MBA)

Married by Accident (MBA) dianggap sebagai faktor $\mathrm{X}$ dalam perkawinan. Hal ini menjadi kejadian luar biasa sehingga dalam kondisi social kemasyarakatan menjadi sebuah aib yang harus ditindaklanjuti dengan cepat. Meskipun dalam keadaan batas usia yang belum mencapai usia perkawinan, tidak dalam persetujuan keluarga atau alasan lainnya maka MBA menjadi solusi ampuh bagi masyarakat bagi pasutri yang mengalami insiden luar biasa ini.

4. Pernikahan kedua setelah duda atau menjanda

Bagi laki-laki atau perempuan yang sudah pernah menikah dan setelahnya menyandang status janda atau duda terkadang merasa sudah tidak perlu mengurus syarat administrasi untuk melangsungkan perkawinan kedua atau seterusnya sehingga mereka merasa bahwa perkawinan bisa dilangsungkan tanpa harus mengurus surat menyurat pada kantor pegawai pencatat nikah, yang penting sah secara agama.

\section{KESIMPULAN}

Sebagai Negara hukum, Indonesia memiliki regulasi untuk mengatur hidup dan kehidupan warganya. Tetapi secara pelaksanaannya regulasi tersebut tidak secara penuh diikuti oleh warga Negara, sehingga terjadi pelanggaran. Hal ini juga dikarenakan tidak adanya sanksi berat bagi yang tidak melaksanakan regulasi tersebut.

Dalam bidang perkawinan pun tidak terlepas dari pelanggaran administrasi yang berkonsekuensi terhadap akibat hokum yang 
merugikan bagi pihak istri dan anak yakni perkawinan yang tidak dicatatkan di depan pegawai pencatat nikah (PPN-KUA). Berdasarkan hasil penelitian pada dua kecamatan dan 6 kelurahan di Kota Bima diperoleh data penyebab terjadinya perkawinan tidak tercatat sebagai berikut:

1. Berpendidikan Rendah

2. Keinginan Poligami (Tanpa Izin Istri Sebelum)

3. Married By Accident (MBA)

4. Pernikahan kedua setelah duda atau menjanda

\section{SARAN}

Dengan adanya fenomena seperti yang sudah diurai di atas, maka hal ini menjadi perhatian semua pihak untuk dapat memberi pemahaman kepada masayarakat tentang pentingnya menikah atau melaksanakan perkawinan melalui pegawai pencatat nikah. Agar kedepannya tidak terjadi penyesalan setelah membentuk keluarga dan memiliki keturunan. Karena secara administrasi tidak bisa ditolerir, dimana sang anak tidak akan mendapatkan akte kelahiran dan tidak bisa melanjutkan ke jenjang pendidikan, dan lain permasalahan yang timbul kemudian hari. Oleh karena itu dalam tulisan ini disarankan kepada semua pihak untuk ikut terlibat memberi pemahaman atau sosialisasi tentang pentingnya perkawinan yang dicatatkan di depan pegawai pencatat nikah.

\section{DAFTAR PUSTAKA}

.Mirri, Mutaminnah A, Kebijakan Itsbat Nikah Terhadap Pernikahan Yang Tidak Tercatat Dalam Buku Register Nikah (Studi Analisis di KUA Kecamatan Singorojo Kabupaten Kendal), 2018, Makasar: UIN Alauddin Makasar Press

Abror, Khoirul "Problematika Nikah Tidak Tercatat Antara Hukum Nasional dan Hukum Islam”, 2013

Anisahuri, 2017, Kemudharatan Nikah yang tidak Tercatat (Analisa Fatwa MUI Nomor 10 Tahun 2008 tentang Nikah di Bawah Tangan), Skripsi tidak diterbitkan.

Fajar, Mukti dan Achmad, Yulianto, 2010, Dualisme Penelitian Hukum:
Normatif \& Empiris, Yogyakarta: Pustaka Pelajar

Hakim, Muhammad Lukman, "Kebijakan Itsbat Nikah Terhadap Pernikahan Tidak Tercatat Dalam Buku Register Nikah (Studi Analisis di KUA Kecamatan Singorojo Kabupaten Kendal)", Tahun 2017, UIN Walisongo Semarang.

Kustini (Ed), 2013, Fenomena Perkawinan Di Bawah Umur Dan Perkawinan Tidak Tercatat, Jakarta: Puslitbang Kehidupan Keagamaan

Raco, J.R. 2013. Metode Penelitian Kualitatif: Jenis, Karakteristik dan Keunggulannya, Jakarta: PT Grasindo

Susanti, Dyah Ochtorina; Shoimah, Siti Nur, "Urgensi Pencatatan Perkawinan (Perspektif Utilities)," Jurnal Rechtidee, Vol. 2 No. 11 tahun 2016

W. Gulo, Metodologi Penelitian, 2010. Jakarta: PT Grasindo

Waluya, Bagja, 2007. Sosiologi: Menyelami Fenomena Sosial di Masyarakat, Bandung: PT Setia Purna Inves 